\title{
Curiosity in Young Children
}

\author{
Mahara Suardi ${ }^{1}$, Leli Kurniawati²,*, Yeni Rachmawati ${ }^{3}$ \\ ${ }^{1,2,3}$ Early Childhood Education, Postgraduate School, Indonesian Education University, Bandung, Indonesia \\ *Corresponding author. Email: leli_kurniawati@upi.edu
}

\begin{abstract}
The era of the industrial revolution 4.0 is a changing development era that integrates cyber and automation technology that have a broad impact throughout the entire field, including education. This caused a great demand for existing human resources as the key to the success of a nation. Some abilities that must be possessed are critical thinking, creative, collaborative, innovative and good communication skills. The phenomenon that occurs, many teachers and parents only provide one-way learning without freeing children to develop their imagination, so that young children are not accustomed to being confronted with a problem that requires them to find solutions to these problems. This article aims to explain how early childhood should be given a habit that requires them to develop their curiosity to prepare them to face competition in the 4.0 revolution era. The method used in this article is a literature review of early childhood curiosity development. The results of the literature review indicate that the development of early childhood curiosity will increase if given the facilities, direction and good habituation to involve them in decision making, and demanded children's participation. This article is expected to provide understanding for teachers and parents in providing learning for early childhood as a millennial generation.
\end{abstract}

Keywords: Curiosity, early childhood, millennial generation.

\section{INTRODUCTION}

Early childhood is immature boy or girl and aged 0-6 years based on the National Education System Law (Sisdiknas). However, according to the National Association for the Education of Young Children (NAEYC), early childhood is $0-8$ years old. The two age limits are no different because they have the same goal to provide education to early childhood at the golden age which will determine their growth and development physically, mentally and intellectually. States that the growth of brain tissue cells in children aged 0-4 years reaches $50 \%$, so that at the age of 8 it reaches $80 \%$ [1]. This means that it is very important to pay attention to children's health, the fulfilment of good and balanced nutrition, and educational services that can stimulate the growth of children's intelligence. Early childhood is the most important developmental stage to form the foundation of children's well-being and future learning [2]. That said, because early childhood development is the key to a productive life for a child and for the progress of a nation in this millennial era.

Early childhood development is influenced by the characteristics of the child, family, and wider social environment. Physical health, cognition, language, and social and emotional development support school readiness [3]. Early childhood is highly motivated to find out and make sense about their world. States that children's understanding will emerge when children try to find a connection between their experiences and their understanding in order to understand their world [4]. Bodrova \& Leong [5] argue that their childhood played a special role in the well-known theory of human culturehistory and biosocial development by the psychologist Lev S. Vygotsky and his circle discussing the role of play in creating a "zone of proximal development" that it is necessary to teach children how to play. Therefore, through stimulating games and toys, children will be able to experiment, discover, and know the whole world around them naturally, while being a fun place to promote intercultural issues.

\section{THE INFLUENCE OF THE INDUSTRIAL REVOLUTION ERA 4.0 ON EARLY CHILDHOOD}

The flow of globalization is unstoppable from entering Indonesia. Accompanied by increasingly sophisticated technological developments, the world is now entering the era of industrial revolution 4.0, which emphasizes the digital economy, artificial intelligence, big data, robotic, and so on, known as the phenomenon of disruptive innovation. At the Early Childhood Education level, preparing for development in order to 
develop properly is an initial requirement, because it will determine the development of subsequent children's learning. It is a challenge not only for early childhood but also for teachers who are required to provide support using technology such as multimedia, the use of gadgets and wifi in the school environment. Several reasons why Indonesia is still less competitive, because of the weakness of higher education and training [6]. The human resources needed by the industry today are those who have competence in the use of digital technology. For this reason, it is necessary to implement a program of up-skilling or reskilling of human resources based on the current needs of the industrial world through one of the competencies needed is human resources who have talent, because talent is a key or important factor. For the successful implementation of industry 4.0 [7]. Invisible skills such as interpersonal skills, global thinking, and media and information literacy. The curriculum must also be able to shape children with an emphasis on the STEM field, referring to learning that has a technology-friendly attitude, collaboration, being creative and taking risks, having a good sense of humor, and whole teaching [8].

Children born after 2010 are the Alpha generation. They were born to millennial generation parents. They are the generation that is most familiar with the internet of all time, the generation that is most familiar with digital technology and the generation that is claimed to be the smartest compared to previous generations. However, they are considered to have flaws, such as: bossy, dominant, and like to control; does not want to share and does not obey the rules. Technology becomes a part of their lives because they would not know the world without social networks; and the ability to communicate directly is much reduced. On the other hand, the development of technology, information and communication occurs rapidly. This development offers both positive and negative sides to the alpha generation who are familiar with the internet. This is where the role of teachers and parents is needed. As one of the institutions responsible for the education of children, teachers and parents are expected to provide right and appropriate care. Millennial parents need to recognize the characteristics of alpha generation children.

Therefore, in order for the alpha generation to become a successful generation in the 21 st century, millennial teachers and parents need to pay attention to the following points: (1) following the developments in technology, information and communication, so that teachers and parents have provisions and can guide children in interacting with the internet smartly and healthily; (2) teaching children to socialize, so that their social-emotional thrive; (3) participating in training and developing the physical-motor aspects of children; (4) participating in equipping children with religious and moral values; (5) educating children not to depend on technology; and (6) playing the maximum role as a discussion partner, a place to ask questions and a place to express affection for children [9].

The occupation of the teacher's position in the teaching role will not be replaced by any sophisticated technology, because the teacher not only teaches but also provides character, moral and role model education to early childhood which cannot be conveyed by other media. According to digital marketing research statistics, the estimated e-marketer/netter population in 2018 the number of active smartphone users in Indonesia is more than 100 people and currently several start-ups in the education sector have developed in the PAUD teacher room from http://anggunpaud.kemendikbud.go.id/ and there is also ruangguru.com, quiper.com. Three skills are predicted to be needed in the future or era of digital literacy 4.0 which leads to the goal of increasing reading, analyzing and making conclusions based on data and information (big data) obtained [10]. Technological literacy aims to provide an understanding of how machines work and technology applications, and human literacy is directed at improving communication skills and design science [11]. So that the style of learning activities in the current knowledge age must be adjusted to the needs of knowledge.

It is said that the 21 st century is marked by the era of 4.0 as the age of globalization, which causes changes in human life, which requires the quality in every human effort. According to Maulana [10] new challenges require a breakthrough thinking process if what is desired is the quality output that can compete with the work of a renewable and open world. This demand calls for critical thinking and high curiosity, the preparation of mature concepts and concrete actions.

This study will try to understand that maybe children are not trying to avoid failure themselves but are driven by a strong desire to solve information gaps by obtaining accurate and objectively relevant knowledge about something complex to a positive learning material for early childhood, where this research aims to produce multimedia products in the form of edutainment with various positive thematic for early childhood with Indonesian local content.

\section{EMBEDDING CURIOSITY IN EARLY CHILDHOOD}

Early childhood education is the stage of recognition of their own identity, where children acquire a series of lessons with stages of curiosity that will contribute to their overall development. Exploring the idea of curiosity as a gateway to appreciating dilemmas in educational practice is one effort that can be made to prepare the millennial generation. Curiosity is a basic element of cognition, although its biological functions, mechanisms, and neural underpinning remain poorly understood, it is nonetheless a motivator for learning, influential in 
decision-making, and crucial for building good understanding [12]. The reflections of the practitioners in three early childhood education and care institutions in Norway are analysed regarding situations in which curiosity was challenging and in which explorative behaviour was stopped, transferred or adjusted. This highlights the entanglement of values, which is part of the ongoing process of constructing professional identity, it is argued that even in the case of widely accepted notions like curiosity [13].

Curiosity is defined as an internal state that occurs when the uncertainty of something causes a tendency to engage in exploratory behavior that aims to resolve or reduce part of the uncertainty [14]. It is made clear by Arnone, Small, Chauncey, \& McKenna [15] that curiosity has been considered a basic instinct, an innate mechanism that allows intelligent species to learn and master new things in their environment, promoting survival, use of tools, and ultimately technological advances. However, curiosity does not automatically progress to a well-developed, individual interest, and a level of engagement that leads to desired outcome of greater learning and mastery.

Curiosity or curiosity is an emotion that allows a person to explore and investigate which is facilitated by the adults in their environment. This facility can be in the form of a curriculum application that makes all aspects of early childhood development. This is in line with the opinion of Hill \& McGinnis [16] that as educators, we have the opportunity to further develop children's thinking skills and perhaps foster children's appreciation for thinking in processes and values that enable them to operate more effectively in the future. It is explained by [17] that through the learning activities, a teacher can encourage curiosity in early childhood which allows them to ask more fundamental questions about what curiosity is and what curiosity is for.

Curiosity is a universal trait of Allah, which is dominated by humans. It underlies the child's development in playing a major role in the learning, discovery and art processes. According to Schattner [18] that, no wonder that curiosity (i.e. ' inquisitiveness) is an established primary goal of education, an acknowledged component of professional competence. That being said, curiosity makes the difference between the usual, familiar practice of facing new challenges, new learning opportunities and new people on each encounter. In line with Tesar's [19] opinion that determining time, place and space can maximize children's development and can free them in the present which is expected to get the desired results.

Family education carried out by parents at home is one of the determinants of children's success in the future, especially in facing the 4.0 era. Era 4.0 fundamentally changes the way parents educate their children. So, being open and determined to continue learning is a must for parents in order to keep up with the development times. Therefore, parents and the whole family must provide education and direction to develop the potential and nature of children. Basically, a child learns many things just by being close to his parents and seeing what they are doing. School is the second environment that can affect children's development. Those who play a role in children's education in schools are teachers / educators. Where the teacher is given the responsibility to continue the education of the child from the parents / family. When a child has entered the school environment, he is considered able to think and is expected to be able to receive lessons from his teacher. The lessons delivered by the teacher are expected to be able to build and develop children's potential according to the needs of the times.

Many things can be done to facilitate children to think creatively, critically and become more innovative. Dunkley \& Smith [20] in their research conducted a series of activities to explore how children recall their memories of childhood experiences in the National Park landscape. Through creative mapping with children, this study questions whether this exposure makes children have environmental awareness. Examining children's creative representations of childhood memories. It retells childhood memories by conceptualizing a slow Eco pedagogy beyond the meeting place to the creative space of storytelling and retelling, which are equally important to memory itself. With these activities, children are required to be able to remember events that have passed to be recounted with their own children's versions.

Identifying the need to develop new ways to study curiosity in the context of today's pervasive millennial technology is to take advantage of the access to information that is already available. Such as interactions in the daily activities of a teacher and children in a preparatory class in Australia in a study conducted by Theobald \& Kultti [21] teachers seek the opinions of children and involve them in decision making, and demand children's participation which sometimes limited by the context and institutional category between teacher and children so as to result in their conversation about what they feel and think. In other research also taking place in Australia and Sweden how children are supported to take an active role in the dimensions of social, economic and political development, as well as environmental management as a concept that requires children's critical thinking as active participants for changes from curriculum [22]

Problem solving that directs questions and seeks answers by students collaborating to create problemsolving solutions in learning. Problem solving that leads to questions and seeking answers by students which can then be a way of solving problems in the context of learning using available information resources. However, are Indonesian educators ready? Teachers are facing the 
revolution era 4.0 when they are still preoccupied with a load of learning tools and coupled with various administrative tasks that are too dense so that they spend a lot of wasted time being creative and innovative in producing works. In the analysis conducted by Maulana $\&$ Nurhafizah [10] regarding early childhood policies in the era 4.0, the opportunity for teachers to produce original works is spent preparing the burden of delivering content that must be prepared before teaching so that social interactions with students are limited, their creativity is shackled, and their moral values are fades away. Thus, a competency is needed that is able to keep up with the presence of these four things, called $21 \mathrm{st}$ century competence.

\section{CONCLUSION}

Dewey's [23] concept of curiosity as a natural resource used in training and Berlyne's ideas about epistemic curiosity are also elaborated. These ideas about the nature of questioning and curiosity help to frame our understanding of the inquiry cycle as a model of learning. They act as a bridge, closing the gap between theory and practice while contributing to open insights into the integration of technology in teaching and learning. Another opinion from Hidi \& Renninger [24] regarding the initial phase of interest development is related to curiosity that is stimulated further ongoing involvement with information seeking that may occur thus showing a contribution to further clarifying the relation between interest and curiosity which is equally important. In another study in Norway, some schools adopted educational orthodoxy, which means that schools would see their responsibility to provide children with a fixed set of frameworks by filling them with the necessary content. This requires children to use what they have learned in new material, by showing curiosity in a defined sense [25].

\section{ACKNOWLEDGMENTS}

The author would like to thank the Indonesian University of Education for providing the opportunity, supporting and assisting the author until the publication of this article and thanks a lot to the reviewer who is willing to guide me in the improvement of this article. Thank you for the stimulating questions about early childhood curiosity that so badly needs to be developed. I hope this article is useful in both academic and nonacademic fields.

\section{REFERENCES}

[1] Priyanto A. Pengembangan kreativitas pada anak usia dini melalui aktivitas bermain. Jurnal Ilmiah Guru Caraka Olah Pikir Edukatif. 2014:18(2):41-47. Available from: https://journal.uny.ac.id/index. php/cope/article/viewFile/2913/2434.
[2] Billingham KA. Developmental psychology for the health care professions. New York: Routledge; 1982.

[3] Anderson LM, Shinn C, Fullilove MT, Scrimshaw SC, Fielding JE, Normand J, Carande-Kulis VG, Task Force on Community Preventive Services. The effectiveness of early childhood development programs: A systematic review. American Journal of Preventive Medicine. 2003;24(3):32-46. Available from: https://fhop.ucsf.edu/sites/ fhop.ucsf.edu/files/ custom_download/PIIS0749379702006554.pdf.

[4] Hedges H. Young children's 'working theories': Building and connecting understandings. Journal of Early Childhood Research. 2014;12(1):35-49. Available from: http://citeseerx.ist.psu.edu/ viewdoc/download?doi=10.1.1.967.3286\&rep=rep1 \&type $=$ pdf.

[5] Bodrova E, Leong DJ. Vygotskian and postvygotskian views on children's play. American Journal of Play. 2015;7(3):371-88. Available from: https://files.eric.ed.gov/fulltext/EJ1070266.pdf.

[6] Ristekdikti. Era revolusi industri 4.0, saatnya generasi millenial menjadi dosen masa depan Sumber Daya IPTEK dan DIKTI [Internet]. 2018;1 6. Available from: http://sumberdaya.ristekdikti. go.id/index.php/2018/01/30/era-revolusi-industri-40 -saatnya-generasi-millennial-menjadi-dosen-masadepan/.

[7] Rohida L. Pengaruh era revolusi industri 4.0 terhadap kompetensi sumber daya manusia. Jurnal Manajemen dan Bisnis Indonesia. 2018;6(1):114-36 Available from: https://fmi.or.id/jmbi/index. php/jurnal/article/download/187/172

[8] Lase D. Pendidikan di era revolusi industri 4.0. SUNDERMANN: Jurnal Ilmiah Teologi, Pendidikan, Sains, Humaniora dan Kebudayaan. 2019;1(1):28-43. Available from: http://jurnal. sttsundermann.ac.id/index.php/sundermann/article/ download/18/16.

[9] Purnama S, Sunan U, Yogyakarta K. Pengasuhan digital untuk anak generasi alpha. Al Hikmah Proceedings on Islamic Early Childhood Education. 2018;1(1):493-502. Available from: https://www.academia.edu/download/57365843/Pe ngasuhan_Digital_48_Sigit_Purnama_493-502.pdf.

[10] Maulana I, Nurhafizah N. Analisis kebijakan pendidikan anak usia dini di era revolusi industri 4.0. Jurnal Pendidikan Tambusai. 2019;3(1):657-65. Available from: https://jptam.org/index. php/jptam/article/download/266/244.

[11] Aoun JE. Robot-proof: Higher education in the age of artificial intelligence. MIT press; 2017. [Internet]. Available from: https://www.researchgate.net/ profile/Patrick_Camilleri2/publication/326432130_ Book_Review_Robotproof_higher_education_in_th e_age_of_artificial_intelligence/links/5ff6c7354585 
1553a026d28f/Book-Review-Robot-proof-highereducation-in-the-age-of-artificial-intelligence.pdf.

[12] Kidd C, Hayden BY. The psychology and neuroscience of curiosity. Neuron. 2015;88(3):44960. Available from: https://doi.org/10. 1016/j.neuron.2015.09.010.

[13] Menning SF. Mapping the dilemmatic space of early childhood education and care practitioners when challenged by children's curiosity. Journal of Early Childhood Research. 2018;16(4):349-62. Available from: https://doi.org/10.1177/1476718X18775769.

[14] Berlyne DE. Curiosity and learning. Motivation and emotion. 1978;2(2):97-175. Available from: https://doi.org/10.1007/BF00993037.

[15] Arnone MP, Small RV, Chauncey SA, McKenna HP. Curiosity, interest and engagement in technology-pervasive learning environments: a new research agenda. Educational Technology Research and Development. 2011;59(2):181-98. Available from: https://www.academia.edu/ download/ 45271063/ETRDfulltext.pdf.

[16] Hill ME, McGinnis J. The curiosity in marketing thinking. Journal of Marketing Education. 2007;29(1):52-62. Available from: https://www. researchgate.net/profile/Mark_Hill8/publication/24 7753003The_Curiosity_in_Marketing_Thinking/lin ks/0a85e534e627641bed000000.pdf.

[17] Phillips R. Space for curiosity. Progress in Human Geography. 2014;38(4):493-512. Available from: https://eprints.whiterose.ac.uk/109121/3/Revised\% 20RSP\%20for\%20PIHG\%20Space $\% 20$ for $\% 20$ Curi osity\%20July\%202013.pdf.

[18] Schattner A. Curiosity. Are you curious enough to read on? Journal of the Royal Social of Medicine [Internet]. 2015;108(5):160-164. Available from: https://journals.sagepub.com/doi/pdf/10.1177/0141 076815585057.

[19] Tesar M. Timing childhoods: An alternative reading of children's development through philosophy of time, temporality, place and space. Contemporary Issues in Early Childhood. 2016;17(4):399-408. Available from: https://journals.sagepub.com/ doi/10.1177/1463949116677924.

[20]Dunkley RA, Smith TA. By-standing memories of curious observations: Children's storied landscapes of ecological encounter. Cultural Geographies. 2019;26(1):89-107. Available from: https://journals. sagepub.com/doi/10.1177/1474474018792652.

[21] Theobald M, Kultti A. Investigating child participation in the everyday talk of a teacher and children in a preparatory year. Contemporary Issues in Early Childhood. 2012;13(3):210-25. Available from: https://journals.sagepub.com/ doi/pdf/10. 2304/ciec.2012.13.3.210.
[22] Ärlemalm-Hagsér E, Davis J. Examining the rhetoric: A comparison of how sustainability and young children's participation and agency are framed in Australian and Swedish early childhood education curricula. Contemporary Issues in Early Childhood. 2014;15(3):231-44. Available from: https:// journals.sagepub.com/doi/pdf/10.2304/ciec.2014.15 .3.231.

[23] Casey L. Questions, curiosity and the inquiry cycle. E-learning and Digital Media. 2014;11(5):510-7. Available from: https://journals.sagepub.com/ doi/pdf/10.2304/elea.2014.11.5.510.

[24]Hidi SE, Renninger KA. Interest development and its relation to curiosity: needed neuroscientific research. Educational Psychology Review. 2019;31(4):833-52. Available from: https://doi. org/10.1007/s10648-019-09491-3.

[25] Opdal PM. Curiosity, wonder and education seen as perspective development. Studies in Philosophy and Education. 2001;20(4):331-44. Available from: https://link.springer.com/article/10.1023/A:101185 1211125 